\title{
Foreword
}

At last, a book focused on one of the real questions.

Years ago, William O'Brien, a very successful CEO and mentor to many of us, said:

I go all around talking with people about values-based, vision-driven businesses. People are always very enthusiastic. It seems as if most people, once given a bit of time to consider this, are quick to declare that, indeed, this is the type of enterprise they want to be part of. This raises an obvious question: If everyone really wants this, why are such businesses so rare? I have come to conclude that most people have no idea of the nature of the commitment required to build such an organization.

Amid the tidal wave of books on sustainable business that have appeared over the past few years, we could readily ask, in the spirit of O'Brien, with so many arguments in favor of green businesses, why are we so far from such enterprises being the norm rather than the exception? Perhaps, as O'Brien suggested many years ago, we are still dancing on the surface of what it takes to build such an enterprise. Maybe the logic of the business case is just not enough, nor the compelling urgency of the societal need, nor the countless examples of good practice. Maybe we simply have not been asking the right questions: How important is this to us? And what is required of those who seek to lead in transforming vision into reality?

The project that led to this book suggests that one answer lies in connecting sustainability and spirituality. I have long found that in Western society we shy away from the word spirituality, mostly for fear of its association with organized religion. (I find this is less of a problem in Eastern societies.) Nonetheless, I have long noticed 
that very practical managers have little trouble with questions like, Have you ever been part of a team that had real spirit? or What have you learned about developing spirit, trust, and commitment within a group of people working together? It seems the phenomenon is far less scary than the abstraction. Indeed, the former strikes most experienced leaders as an essential matter, while the latter remains optional or even problematic for many.

Fortunately, in my experience, the former is the gateway to addressing O'Brien's challenge. How do we tap passion, energy, imagination, perseverance and willingness to truly grow as a human being, in ourselves and collectively? How do we recognize and cultivate people's innate sense of concern for matters beyond themselves? How do we connect this concern and willingness to creating products, processes, and business models that address the major issues of our time-food, water, energy, waste and toxicity, youth underemployment and unemployment, and the widening gap between rich and poor?

These are the types of questions that I believe could get businesses out of neutral regarding sustainability. They offer channels of deep inquiry that could mobilize energy and a sense of possibility in what is all too often a "follow the other guy" industry of modest changes that inspire modest commitment. There are no shortages of great ideas to latch onto, once we have started to light the fires waiting to be lit. There are already countless smaller enterprises creating new businesses around these questions, and a small but growing number of large global businesses, such as Nike, which is committed to zero waste, zero toxins and complete closed loop manufacture by 2020 ," and Unilever, which has transformed itself over the past decade and a half from a sleepy noninnovative, nongrowth company into one of Europe's most dynamic, attractive employers, and whose core strategy—its Sustainable Living Planinvolves doubling sales this decade while reducing the company's environmental footprint in absolute terms and bringing millions of "small holders" into its global food chains. Unilever CEO Paul 
Polman bluntly and regularly reminds us that you cannot grow a healthy business in an unhealthy society.

Being true to its pragmatic imperative can also enable a business to overcome what I see as the primary problem with the word spirituality, which is too often heard as a matter of beliefs and convictions rather than practices. Practices that shift how we think and interact will help people both in getting things accomplished and in shifting the place from which we operate in our accomplishing. There are many who see themselves as spiritual people who are seen as a bit less so by those who observe their actions. It is only through practices that we can break down deep individual and collective habits, which is why half of this book is devoted to practices at the individual, team, organization, and system levels.

Having railed about "spirituality," I should add that I do not much like the word sustainability either, nor its more politically correct cousin, sustainable development. Besides being ambiguous, these words tell us only that we have a problem to solve-we are "unsustainable"-but they stir little in the mind or soul toward its solving. My ambivalence for the term was crystallized many years ago when I heard green chemist Michael Braungart say, "If someone asked you how your marriage was and you said, 'It's sustainable,' this would not be a good thing." As a rallying cry, sustainability fails O'Brien's test question miserably. It inspires not an inkling of understanding of the nature of the commitment needed to move reality toward the vision-indeed, for many it subtly suggests that the costs will be great and the eventual reality quite uninspiring.

Sustainability is a bit like visiting relatives who have overstayed their welcome. Politeness compels you to attend to them, but you worry that the more you do, the longer they are likely to stay. I for one am ready to stop attending and hope that we will awake one day, sooner rather than later, to discover that we simply do not need the word any longer-the unwanted relatives will have moved on.

But I am now illustrating the very sin I am complaining about. I am 
pointing out the problem and failing completely to evoke a sense of a solution. To correct myself, let me try it this way. There is no way we will shift the overall course of our society unless we begin to see a future that is more inspiring than the past, more in line with what we deeply care about, and more exciting than business as usual. We cannot overcome lack of commitment with better analysis.

Words matter. In seeking to animate a latent cause so vital to our future, we must find our way to articulating a purpose that taps our genuine aspirations and inspires our bountiful imaginations. No less a master of English than George Bernard Shaw said it: "This is the true joy in life, the being used for a purpose recognized by yourself as a mighty one; ... the being a force of nature rather than a feverish, selfish little clod of ailments and grievances complaining that the world will not devote itself to making you happy. ${ }^{\text {" }}$ An indicator of real progress in our mission may be letting go of the negative vision of "not being unsustainable" for a positive vision—like "flourishing."

Perhaps this book can help us start to do just that. I applaud the authors' courage in tackling questions that really matter-such as "What do we call that which we are seeking to create?" and "What is the nature of commitment to our own awakening required by the undertaking?"

At the very least, this book will help readers think more deeply about these questions. At best, it may help us lose the dimly lit path we are now slogging along in favor of a truer one.

Peter Senge, Cambridge, Massachusetts, May 2014 


\section{Flourishing Enterprise}


